\title{
Review
}

\section{Daily Lifestyle and Cutaneous Malignancies}

\author{
Yu Sawada * and Motonobu Nakamura
}

Department of Dermatology, University of Occupational and Environmental Health 1-1, Iseigaoka, Yahatanishi-ku, Kitakyushu, Fukuoka 807-8555, Japan; motonaka@med.uoeh-u.ac.jp

* Correspondence: long-ago@med.uoeh-u.ac.jp

Citation: Sawada, Y.; Nakamura, M. Daily Lifestyle and Cutaneous Malignancies. Int. J. Mol. Sci. 2021, 22, 5227. https://doi.org/10.3390/ ijms22105227

Academic Editors: Philip W. Wertz and Terrence Piva

Received: 5 May 2021

Accepted: 13 May 2021

Published: 14 May 2021

Publisher's Note: MDPI stays neutral with regard to jurisdictional claims in published maps and institutional affiliations.

Copyright: (c) 2021 by the authors. Licensee MDPI, Basel, Switzerland. This article is an open access article distributed under the terms and conditions of the Creative Commons Attribution (CC BY) license (https:/ / creativecommons.org/licenses/by/ $4.0 /)$.

\begin{abstract}
Daily lifestyle is a fundamental part of human life and its influence accumulates daily in the human body. We observe that a good daily lifestyle has a beneficial impact on our health; however, the actual effects of individual daily lifestyle factors on human skin diseases, especially skin cancers, have not been summarized. In this review, we focused on the influence of daily lifestyle on the development of skin cancer and described the detailed molecular mechanisms of the development or regulation of cutaneous malignancies. Several daily lifestyle factors, such as circadian rhythm disruption, smoking, alcohol, fatty acids, dietary fiber, obesity, and ultraviolet light, are known to be associated with the risk of cutaneous malignancies, malignant melanoma, squamous cell carcinoma, basal cell carcinoma, and Merkel cell carcinoma. Although the influence of some daily lifestyles on the risk of skin cancers is controversial, this review provides us a better understanding of the relationship between daily lifestyle factors and skin cancers.
\end{abstract}

Keywords: daily lifestyle; skin cancer; melanoma; squamous cell carcinoma; basal cell carcinoma; merkel cell carcinoma

\section{Introduction}

Human beings are constantly exposed to various environmental stimuli and have developed their ability to adapt to these external factors, such as circadian rhythm, food intake, ultraviolet light, and microorganisms [1-3]. Among these environmental factors on Earth, daily lifestyle is a fundamental part of human life and influences human health. For instance, the influence of lifestyles, such as dietary foods and luxury consumptions, accumulates daily and affects human health [4-6]. Therefore, these influences are helpful information for clinicians to understand the detailed molecular pathogenesis of daily lifestyle-related human diseases.

The skin is the outmost layer organ and is one of the most exposed human organs to environmental stimuli [7]. This fact prompts us to speculate that daily lifestyle might well influence the risk of skin diseases. In addition, the skin is composed of various cells, such as keratinocytes, melanocytes, immune cells, and adipocytes [8]. This is the reason why daily lifestyle might broadly influence the risk of cutaneous malignancies.

Recent information on skin cancers gained from novel technologies such as in vivo reflectance confocal microscopy promotes deep understanding of the detailed molecular mechanisms of skin cancer development [9-11]. However, its advanced form is intractable and there are still only a limited number of therapeutic options against metastatic lesions of skin tumors. Therefore, how the accumulation of daily lifestyle factors influences skin cancer development is helpful information for clinicians.

In this review, we focused on the daily lifestyle influences on human cutaneous malignancies. First, we introduce representative skin malignancies and then, describe how each factor of daily lifestyle influences the development or regulation of skin malignancies. Ultraviolet light causes DNA damage, which leads to cancer formation and is one of the main risks to skin cancer. The role of ultraviolet light irradiation in the development of skin cancer has already been intensively reviewed in a lot of papers [12]. Therefore, this review only focused on major daily lifestyle factors, including UV irradiation. 


\subsection{Daily Lifestyle-Related Malignancies}

Daily lifestyle is closely related to the risk of skin tumors, such as malignant melanoma, basal cell carcinoma, squamous cell carcinoma, and Merkel cell carcinoma. First of all, the characteristics of these malignancies are briefly introduced.

\subsection{Malignant Melanoma}

Melanoma is a malignancy derived from melanocytes, with an unfavorable lifethreatening clinical behavior due to its malignant characteristics in addition to a limited number of radical treatments $[13,14]$. The tumorigenesis of melanoma is associated with several gene mutations in BRAF, NRAS and C-KIT, which are correlated with the histopathological characteristics of melanoma [15-17]. One of the most common mutations is the BRAF gene, whose inhibition showed a beneficial antitumor reaction against melanoma [18].

The BRAF gene is located on chromosome 7 (7q34) and encodes the BRAF protein [19], which is involved in the activation of the mitogen-activated protein kinase (MAPK) pathway [20], leading to the regulation of cell growth, differentiation, proliferation and apoptosis [21]. BRAF has been identified as a commonly mutated gene in human tumors [22]. Mutations in the BRAF gene could cause an impaired protein function [23], and $\mathrm{BRAF}^{\mathrm{V} 600}$ mutations have been detected in nearly $50 \%$ of malignant melanoma and activate the downstream pathway of MAPK [24] (Figure 1).

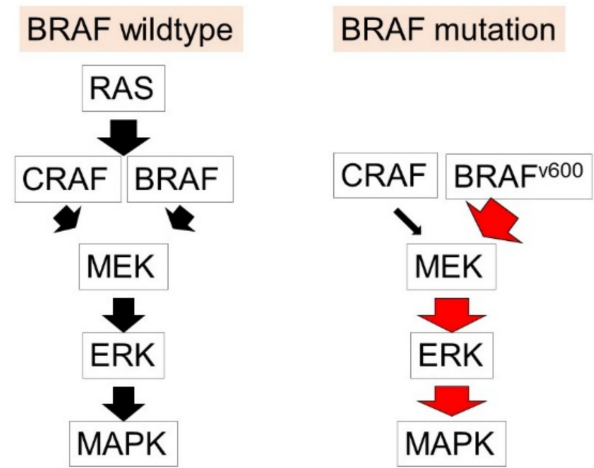

Figure 1. The mechanisms of development of melanoma. In BRAF wild type melanoma, RAS is one of the non-BRAF oncogenes activated in melanoma and promotes cellular functions in melanoma, including the promotion of cell growth and apoptosis. They activate downstream signaling pathways MEK/ERK, MAPK, and the PI3K/AKT pathways. In the BRAF mutation melanoma, BRAFV600 mutations activate the downstream pathway of MAPK and exert the development and progression of melanoma.

NRAS mutations are the second most frequent mutations in malignant melanoma [25]. RAS proteins control the MAPK and PI3K pathways. C-KIT is also important for the pathogenesis of melanoma, especially acral and mucosal melanoma [26,27]. Cyclin-dependent kinase inhibitor type 2A (CDKN2A) has also been identified as a major gene associated with the risk of melanoma [28]. Although there are severe adverse therapeutic reactions [29-31], recent advancements in immunotherapy targeted against PD-1 or CTLA-4 have dramatically improved clinical outcomes in advanced forms of melanoma via inhibition of the escape phenomenon from antitumor immunity, which is mediated by these molecules [32-36]. Although the current development of immune checkpoint inhibitors and BRAF-targeted treatment has improved their clinical outcomes, these therapies do not reach a satisfactory level of clinical outcomes. Circadian rhythm, smoking, alcohol, vitamin A, obesity, fatty acids, coffee/caffeine, and ultraviolet light are known to be associated with the risk of malignant melanoma. 


\subsection{Squamous Cell Carcinoma}

Cutaneous squamous cell carcinoma is a cutaneous malignancy derived from keratinocytes in the skin and is a highlighted issue for clinicians because of its current increasing incidence rate in the world [37,38]. The advanced metastasis of cutaneous squamous cell carcinoma shows an unfavorable clinical behavior due to there being a limited number of effective treatments $[39,40]$. A tumor suppressor gene, p53, is closely related with the development of cutaneous squamous cell carcinoma, and mutation of the p53 gene is an important step in the development of SCC [41]. The p53 gene is responsible for cell cycle arrest, apoptosis, and DNA repair as a tumor suppressor gene. Once p53 gene mutation occurs, these cell functions lose control and develop the tumor by promoting tumor growth, cell survival, and DNA repair disruption (Figure 2). Ultraviolet light exposure, circadian rhythm, smoking, alcohol, dietary fiber, citrus intake, obesity, and fatty acids are related to the risk of cutaneous squamous cell carcinoma.
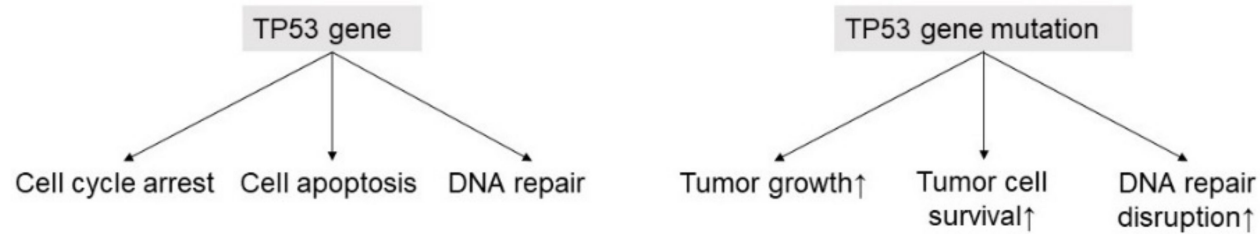

Figure 2. p53 gene and tumor development. A brief schema of p53 and tumorigenesis. p53 gene is responsible for cell cycle arrest, apoptosis, and DNA repair as a tumor suppressor gene. Once p53 gene mutation occurs, these cell functions lose control and develop the tumor by promoting tumor growth, cell survival, and DNA repair disruption.

\subsection{Basal Cell Carcinoma}

The nomenclature for basal cell carcinoma is explained by the histomorphological resemblance of cancer cells to basal cells of the epidermis [42]. Although the metastatic form is rare, a local invasion is commonly observed. In addition, mutations in hedgehog pathway genes primarily involve patched homolog (PTCH) and smoothened homolog (SMO); hedgehog pathway inhibition by vismodegib showed an antitumor response against invasive metastatic basal cell carcinoma [43]. Mutations of p53 and the PTCH gene are major candidate tumor suppressor genes for basal cell carcinoma [44]; once UV-induced, these gene mutations are related with the tumorigenesis of basal cell carcinoma $[45,46]$. In addition, circadian rhythm, smoking, alcohol, furocoumarin intake, obesity, fatty acids, coffee/caffeine, and ultraviolet light are associated with the risk of basal cell carcinoma.

\subsection{Merkel Cell Carcinoma}

Merkel cell carcinoma is an uncommon aggressive cutaneous malignancy with a high rate of local recurrence and distant metastasis, despite radical surgical resection. Recent studies identified that Merkel cell polyoma virus is among the pathogeneses. Polyomavirusencoded $\mathrm{T}$ antigens target several tumor suppressor proteins, such as the retinoblastoma protein (RB) and p53 protein [47]. In particular, large T antigen (LTA) contributes to the tumorigenesis by suppression of the cell cycle regulatory function of RB, while LTA antigens lack a putative p53-binding domain because of tumor-associated LTA mutations [48,49]. On the other hand, there are many UV-mediated mutations in Merkel cell polyoma virusnegative patients [50]. Therefore, among daily lifestyle-related factors, it is thought that UV radiation is one of the major triggers for the development of Merkel cell polyoma virus-negative Merkel cell carcinoma.

\section{The Daily Lifestyle Associated with the Cutaneous Malignancies}

In this section, we introduce the risk of cutaneous malignancies associated with representative daily lifestyles, such as sleeping, smoking, alcohol intake, dietary fiber, obesity, fatty acid, coffee/caffeine, vegetables, and ultraviolet light. In addition, the 
detailed molecular mechanisms of advancement or regulation of cutaneous malignancies in some parts of daily lifestyle factors are also described.

\subsection{Circadian Rhythm}

A day on earth is around $24 \mathrm{~h}$; however, the internal clock period of the human body is closer to $25 \mathrm{~h}$ [51]. Therefore, adaptation to the earth's daily cycle is essential for animals living on Earth, and the human body has been developed to adjust to the Earth's daily cycle period through regulation of the circadian rhythm. Disruption of the circadian rhythm negatively affects human health, which is becoming a global health threat, including metabolic and immune diseases [52]. Since the circadian rhythm regulates daily fluctuations in immune response, it is assumed that circadian disruption results in an impaired tumor-associated immune response and facilitates tumor growth. In fact, the epidemiological study identified that night shift work is associated with a high risk of several cancers [53]. Shift work with circadian disruption is also associated with the risk factor for cutaneous malignancies.

\subsubsection{Melanoma and Circadian Rhythm}

Recent systematic review analysis revealed that shift work is associated with an increased risk of melanoma [54]. As detailed molecular mechanisms, circadian clock gene expression depends on the development of melanoma. Disruption of the circadian rhythm developed tumor growth in a murine melanoma model and impaired inflammatory reaction in M1 macrophages-mediated antitumor immunity in a mouse experiment [55]. Interestingly, circadian regulation genes are reduced in melanoma [56-58]. The expression of the clock gene aryl hydrocarbon receptor nuclear translocator-like protein 1 (BMAL1) shows a positive correlation with the overall survival, T-cell activity, and the beneficial impact of immune checkpoint inhibitors [59]. Although the clock genes are suppressed in melanoma, treatments of circadian rhythmicity by dexamethasone trigger the recovery of rhythmic clock and cell cycle gene expression, which result in low frequency in the $S$ phase tumor cell and high frequency in the G1 phase. In addition, silencing BMAL1 impaired the effects of dexamethasone on tumor growth of melanoma in an in vitro experiment [60]. Clock gene disruption in melanoma is associated with decreased light-dependent activation of DNA repair genes [61].

\subsubsection{Squamous Cell Carcinoma/Basal Cell Carcinoma and Circadian Rhythm}

A recent systematic review analysis of the relationship between skin cancer and shift work revealed that shift work is associated with a significant decreased risk of basal cell carcinoma [54]. However, this systematic review could not detect a significant difference between shift work and the risk of squamous cell carcinoma. Although there are a limited number of studies focused on the role of clock genes in cutaneous squamous cell carcinoma, squamous cell carcinoma originating from the oral and head/neck, not from the skin, show an increased risk of tumor development by disruption of the circadian rhythm. Abnormal expression of the clock gene PER1 shows a correlation with the tumorigenesis of squamous cell carcinoma [62]. PER1 is decreased in squamous cell carcinoma [63,64] and low expression of PER1 is closely related to unfavorable clinical behavior, such as developed lymph node metastasis and advanced clinical stage [64,65], and poor survival [66]. Consistently silencing PER1 in melanoma cells promotes tumor proliferation $[62,67,68]$ and development in an in vitro experiment [69], while overexpression of PER1 enhances the apoptosis of squamous cell carcinoma [64]. PER2 expression is also decreased in squamous cell carcinoma [70,71] and decreased PER2 expression is associated with advanced clinical stage, lymph node metastasis, and unfavorable patient survival [70]. Silencing PER2 in melanoma cells reduces the apoptosis of tumor cells [72-74] and induces tumor development in an in vitro experiment [69]. Consistently high expression of PER2 negatively regulates tumor development [71]. The expression of PER3 is significantly downregulated in the tumor [66], which is associated with advanced tumor stages, tumor size, tumor inva- 
sion, and unfavorable patient survival [66]. The circadian clock gene BMAL1 suppresses tumor development in tongue squamous cell carcinoma [66,75]. The degree of BMAL1 expression is related to the clinical course and BMAL1 expression is downregulated in tongue squamous cell carcinoma, leading to a high frequency of tumor cell invasion and metastasis [75]. Consistently, the suppression of BMAL1 results in the development of the tumor [69].

\subsection{Smoking}

Tobacco smoking is a representative daily lifestyle-related habit, which has a long history in human beings [76]. Although a large population still continues this habit in their daily lifestyle, tobacco smoking is also recognized worldwide as a harmful substance for human health that causes various organ disorders and malignancies [77-79]. The skin is also known to be involved in smoking-related human diseases.

\subsubsection{Melanoma and Smoking}

Although smoking is negatively associated with melanoma incidence [80-82], smoking is not associated with melanoma-specific mortality [82] or sentinel lymph node metastasis [83]. On the contrary, another study also identified that current smoking is associated with sentinel lymph node metastasis and tumor ulceration [84]. Never smoking is associated with decreased tumor thickness in melanoma [84].

\subsubsection{Squamous Cell Carcinoma/Basal Cell Carcinoma and Smoking}

The influence of smoking on the risk of squamous cell carcinoma is controversial. Some studies showed that current smoking is associated with an increased incidence of squamous cell carcinoma [85-87], while other studies could not find a significant influence of smoking on the risk of squamous cell carcinoma in smokers [88,89].

The influence of smoking on the risk of basal cell carcinoma is also controversial. Current smoking and heavy smoking conditions are associated with a decreased risk of basal cell carcinoma [90-93], while several studies could not detect a significant risk of basal cell carcinoma in smokers $[85,86,94-98]$. However, the prevalence of clinical subtype of basal cell carcinoma might be associated with smoking. One study identified that morpheatype basal cell carcinoma exhibits a significantly high frequency in smokers compared to solid basal cell carcinoma [99].

\subsection{Alcohol}

Alcohol is one of the major human daily lifestyle-related factors with a long-lasting history of being a habit in humans. Since alcohol intake is a common lifestyle choice in the world, it is important to understand the actual effect of alcohol on human diseases in daily clinical practice. Indeed, there are many alcohol-related influences on human diseases that have both beneficial and detrimental effects. Cutaneous malignancies are also influenced by alcohol intake.

\subsubsection{Melanoma and Alcohol}

The risk of alcohol in melanoma was controversial in each individual statistical analysis [100-108]; however, a meta-analysis that included 16 studies with a total of 6251 cases of cutaneous melanoma revealed that the relative risk of malignant melanoma is increased in the alcohol intake group [109].

\subsubsection{Squamous Cell Carcinoma/Basal Cell Carcinoma and Alcohol}

The risk of basal cell carcinoma in alcohol intake was controversial in each individual statistical analysis [96,110-113]. However, a systematic review identified evidence that alcohol drinking is closely related to the risk of basal cell carcinoma in a dose-dependent manner [114]. The systematic literature studies were case-control or cohort studies that examined alcohol intake and risk of BCC and a total of 91,942 basal cell carcinoma pa- 
tients and 3299 cutaneous squamous cell carcinoma patients were investigated. Alcohol intake showed a positive correlation with the risk of basal cell carcinoma and squamous cell carcinoma.

\subsection{Dietary Fiber/Vegetables/Fruits}

Dietary fiber is a non-digestible substance consistent with the plant cell wall. Dietary fiber includes important plant materials for human health, such as polysaccharides, oligosaccharides, and lignin [115]. We can commonly intake dietary fiber by eating vegetables; however, the consumption of a fiber-rich diet is currently decreasing. Current studies showed dietary fiber substances, vegetables and fruits have beneficial effects on human health. Therefore, these influences are important for clinicians to better understand the regulation of cutaneous malignancies.

\subsubsection{Melanoma and Dietary Fiber/Vegetables/Fruits}

Several studies identified a significant negative correlation between vitamin A intake and melanoma risk $[108,116,117]$. However, no significant association is observed between furocoumarins consumption and the risks of melanoma [118]. Dietary fiberderived short-chain fatty acids are produced from bacteria under anaerobic conditions and have various bioactive actions against immune cells and epithelial cells [2]. Dietary fiberderived short-chain fatty acid butyrate promotes melanoma cell invasion by the induction of Annexin A1 (ANXA1), which negatively regulated E-cadherin expression in an in vitro experiment [119].

\subsubsection{Squamous Cell Carcinoma/Basal Cell Carcinoma and Dietary Fiber/Vegetables/Fruits}

A higher intake of total furocoumarins is associated with a high risk of basal cell carcinoma $[118,120,121]$. There is no association between citrus fruits intake and the risk of cutaneous squamous cell carcinoma [118,121,122]. One study identified a negative correlation between a high total citrus intake and the risk of squamous cell carcinoma [120]. An epidemiological study showed that fiber intake is negatively associated with the risk of esophagus squamous cell carcinoma [123].

\subsection{Obesity}

Since human beings have developed into a modern civilization, we can easily obtain enough food and do not necessarily require physical activity due to the development of transportation. An excessive food intake or insufficient physical activity causes obesity, which develops various physiological and pathological changes in the human body due to disruption of the energy balance. Therefore, obesity-related human diseases are highlighted for clinicians. Current studies identified that obesity is closely related to the development of cutaneous malignancies.

\subsubsection{Melanoma and Obesity}

The relationship between obesity and the risk of melanoma is controversial. One study reported that obesity is significantly associated with a risk of melanoma thickness [124]; however, several studies could not find a relationship between the risk of melanoma and obesity [125-127]. Obesity significantly increases the risk of melanoma in individuals younger than 50 years old, whereas this association is not significant in people over 50 years old [128]. Body mass index at age 20 is significantly associated with the risk of melanoma [129].

\subsubsection{Squamous Cell Carcinoma/Basal Cell Carcinoma and Obesity}

Body mass index in the obese range showed a 32\% lower risk of squamous cell carcinoma compared to that in the normal range [127]. Another study showed a high relative risk of squamous cell carcinoma in obese females only [126]. Obese female patients 
showed a decreased risk of basal cell carcinoma [126]. In another study, a body mass index in the obese range showed a 19\% lower risk of basal cell carcinoma [127].

\subsection{Fatty Acids}

A fatty acid is a carboxylic acid with a long aliphatic chain, which is either a saturated or unsaturated fatty acid [6]. Fatty acids are important dietary sources of fuel for animals and are essential structural components for cells. Recent studies identified that fatty acids have bioactive actions in the human body with physiological and pathological effects. In the skin, fatty acids, such as prostaglandins and leukotrienes, positively and negatively drive inflammatory skin diseases and contribute to the development of cutaneous malignancies [130-133]. Furthermore, omega-3 fatty acids and their metabolites derived from fish and nuts have a beneficial impact on human skin diseases [134-136].

\subsubsection{Melanoma and Fatty Acids}

The "high-fish, low-meat, and low-fat" dietary pattern is not associated with the risk of melanoma thickness [133]. The risk of melanoma increases with the intake of omega-6 fatty acids [137] and decreases with the intake of omega-3 fatty acids [138]. Tumor growth is suppressed by omega-3 fatty acids [139], such as DHA [140,141]. Tumor invasion in melanoma is promoted by arachidonic acid [142] and PGE2 [142], while this is suppressed by omega-3 fatty acids [143], such as EPA [142] and DHA [142].

Several experimental studies identified the detailed molecular relationship between tumor regulation and fatty acids. DHA reduces the migration/invasion of melanoma by down-regulating several matrix metalloproteinases, such as MMP-2 and MMP-13, which are involved in melanoma invasion [141]. DHA and EPA enhance cisplatin-induced inhibition of tumor growth and migration [144]. Omega-6 fatty acids induce CXCR4 expression in melanoma, although $\omega 3$ fatty acids decrease CXCR4 expression, leading to the prevention of melanoma metastasis [145]. Leukotriene B4 (LTB4), which induces growth of melanoma cells, and an LTB4 receptor antagonist inhibit acute inflammationassociated tumor growth [146]. The eicosapentaenoic acid-derived leukotriene, leukotriene B5, significantly suppresses the development of tumors [146]. DHA metabolites Resolvin D1 (RvD1) and Resolvin D2 (RvD2) suppress melanoma tumor cell growth [147], and the metastasis of melanoma cells.

\subsubsection{Squamous Cell Carcinoma/Basal Cell Carcinoma and Fatty Acids}

A high intake of omega-3 PUFA shows a substantially reduced risk of squamous cell carcinoma [148], and a high plasma level of EPA concentration is associated with a lower risk of squamous cell carcinoma [149]. Arachidonic acid intake has a marginally increased risk of squamous cell carcinoma [149]. On the contrary, those with high omega-6 fatty acid and $\alpha$-linolenic acid intakes show a significantly lower risk of basal cell carcinoma $[148,149]$. A decreased risk of basal cell carcinoma is associated with a higher serum concentration of total omega-6, linoleic acid, and linolenic acid serum concentrations [150]. A higher omega- 6 fatty acids intake is associated with the risk of basal cell carcinoma [137]; however, the association between omega- 3 fat intake and the risk of squamous cell carcinoma and basal cell carcinoma could not be detected by a meta-analysis [138].

Several experimental studies showed the beneficial potential of omega-3 fatty acids on the regulation of squamous cell carcinoma. Omega-3 fatty acids exhibit the inhibition of tumor growth of both basal cell carcinoma and squamous cell carcinoma and modulate the immune response [151]. A DHA metabolite RvD2 has antitumor effects against squamous cell carcinoma [152]. RvD2 shows anti-inflammatory action and suppresses inflammatory cytokines and chemokines by tumor cells.

\subsection{Coffee/Caffeine}

Drinking coffee is a broadly familiar human daily lifestyle factor and habit in the world. Coffee consists of more than 1000 components, responsible for its aroma and flavor, 
and shows physiological and pathological activities to the human body [153]. Coffee and caffeine are closely related to the development of cutaneous malignant tumors.

\subsubsection{Malignant Melanoma and Coffee/Caffeine}

Coffee and caffeine are associated with a low risk of malignant melanoma [154-156], which is more apparent for melanomas occurring on body sites with higher continuous sun exposure (head, neck, and extremities) [156]. Consistently, the meta-analysis also supports the finding of a low risk of melanoma through coffee consumption [157], but not decaffeinated coffee [158]. One study reported that coffee consumption is negatively associated with melanoma risk among men, but not among women [159].

\subsubsection{Squamous Cell Carcinoma/Basal Cell Carcinoma and Coffee/Caffeine}

Caffeine intake decreases the risk of basal cell carcinoma [160,161]. Combined caffeinated coffee plus hot tea consumption is also negatively associated with the risk of basal cell carcinoma [162], while there is no association between decaffeinated coffee consumption and the risk of basal cell carcinoma [163]. However, one study could not detect the association between total caffeine intake and incidence of basal cell carcinoma or squamous cell carcinoma [160].

\subsection{Ultraviolet Light Exposure}

The skin is necessarily exposed to sunlight and a part of it is ultraviolet light, which is classified as UVA, UVB and UVC. UVB damages DNA more effectively than UVA. Ultraviolet light is responsible for damage to DNA and gene mutations, including mutations of the p53 gene [164].

\subsubsection{Melanoma and Ultraviolet Light}

Ultraviolet light exposure is a risk factor of melanomagenesis [165,166]. Ultraviolet light-induced DNA damage is mediated by p53, whose functional deletion drives ultraviolet light-mediated melanoma development [167]. p53 was also shown to cooperate with $\mathrm{BRAF}^{\mathrm{V} 600}$ mutation to induce melanoma in the presence of ultraviolet light [168]. Interestingly, among $\mathrm{BRAF}^{600}$ mutations, the $\mathrm{BRAF}^{600 \mathrm{k}}$ mutation is significantly correlated with ultraviolet light exposure compared with the $\mathrm{BRAF}^{600 \mathrm{E}}$ mutation [169].

\subsubsection{Squamous Cell Carcinoma and Ultraviolet Light}

Ultraviolet light radiation is one of the triggers of the development of cutaneous squamous cell carcinoma [170] and increases risk of it [45]. The mechanism is thought to be UVB-induced inactivation of p53, accounting for approximately $58 \%$ of cutaneous squamous cell carcinoma [171]. In fact, p53-deficient mice showed the development of cutaneous squamous cell carcinoma due to UVB exposure [172].

\subsubsection{BCC and Ultraviolet Light}

Ultraviolet light increases the risk of basal cell carcinoma [45]. Ultraviolet light causes p53 mutation, which is associated with an increased risk of basal cell carcinoma [46]. Mutations in hedgehog pathway genes primarily involve the genes encoding PTCH and SMO. UVB radiation increases the gene expression of Ptch2, Smo and Gli1 [173].

\subsubsection{Merkel Cell Carcinoma and Ultraviolet Light}

The gene expression of LTA increases after UV radiation [174] and ultraviolet light radiation increases the risk of Merkel cell carcinoma [165]. There is a greatly increased incidence of Merkel cell carcinoma among fair-skinned individuals compared to its incidence in those with darker skin [50]. The tumor develops on sun exposure site skin such as the face, scalp, and arms [175]. 


\section{Recommendations}

Although there are controversial results in some parts, we summarized the risk of skin cancer by daily lifestyle factors (Table 1). Circadian rhythm disruption increases the risk of melanoma and decreases the risk of basal cell carcinoma. Smoking increases the risk of squamous cell carcinoma, but decreases the risk of melanoma and basal cell carcinoma. Obesity decreases the risk of basal cell carcinoma, but increases the risk of melanoma. Omega-3 fatty acids decrease the risk of melanoma, squamous cell carcinoma, and basal cell carcinoma, and omega- 6 fatty acids increase the risk of melanoma and squamous cell carcinoma. Coffee/caffeine decreases the risk of melanoma and basal cell carcinoma. Ultraviolet light exposure increases the risk of melanoma, squamous cell carcinoma, basal cell carcinoma, and Merkel cell carcinoma.

Table 1. The relationship between daily lifestyle factors and the risk of skin cancers.

\begin{tabular}{|c|c|c|c|c|}
\hline & Melanoma & $\begin{array}{l}\text { Squamous Cell } \\
\text { Carcinoma }\end{array}$ & $\begin{array}{l}\text { Basal Cell } \\
\text { Carcinoma }\end{array}$ & $\begin{array}{l}\text { Merkel Cell } \\
\text { Carcinoma }\end{array}$ \\
\hline $\begin{array}{l}\text { Circadian rhythm } \\
\text { disruption }\end{array}$ & Risk up [54] & No association [54] & Risk down [54] & \\
\hline Smoking & Risk down [80-82] & $\begin{array}{c}\text { Risk up [85-87] } \\
\text { No association } \\
{[88,89] .}\end{array}$ & $\begin{array}{c}\text { Risk down [90-93] } \\
\text { No association } \\
{[85,86,94-98] .}\end{array}$ & \\
\hline Alcohol & Risk up [109] & Risk up [114] & Risk up [114] & \\
\hline $\begin{array}{c}\text { Dietary } \\
\text { fiber/vegetables/fruits }\end{array}$ & $\begin{array}{c}\text { Vitamin A: Risk } \\
\text { down [108,116,117] } \\
\text { Furocoumarins: No } \\
\text { association [118] }\end{array}$ & $\begin{array}{c}\text { Citrus: Risk down } \\
\text { [120] } \\
\text { No association } \\
{[118,121,122]} \\
\end{array}$ & $\begin{array}{l}\text { Furocoumarins: Risk } \\
\text { up }[118,120,121]\end{array}$ & \\
\hline Obesity & $\begin{array}{c}\text { Risk up }[124,128,129] \\
\text { No association } \\
{[125-127]}\end{array}$ & $\begin{array}{c}\text { Risk up [126] } \\
\text { Risk down [127] }\end{array}$ & Risk down $[126,127]$ & \\
\hline Fatty acids & $\begin{array}{l}\text { omega-3 fatty acid: } \\
\text { Risk down [138] } \\
\text { omega-6 fatty acid: } \\
\text { Risk up [137] }\end{array}$ & $\begin{array}{c}\text { Omega-3 fatty acid: } \\
\text { No association [138] } \\
\text { Omega-6 fatty acid: } \\
\text { Risk up [149] }\end{array}$ & $\begin{array}{c}\text { Omega-3 fatty acid: } \\
\text { No association [138] } \\
\text { Omega-6 fatty acid: } \\
\text { Risk up [137] }\end{array}$ & \\
\hline Coffee/caffeine & Risk down [154-156] & & Risk down [160-162] & \\
\hline Ultraviolet light & Risk up $[165,166]$ & Risk up $[45,170]$ & Risk up $[45,46]$ & Risk up $[165,176]$ \\
\hline
\end{tabular}

\section{Conclusions}

This review presents the influence of daily lifestyle on skin malignancies. Daily lifestyle has diverse aspects and there is a possibility that daily lifestyle factors act in an integrated complex manner. In addition to the physiological and pathological effects of a single daily lifestyle factor, knowledge of the more multifaceted effects of daily lifestyle might be necessary to obtain a better understanding of actual daily lifestyle influence on cutaneous malignancies. Furthermore, there are largely unknown molecular mechanisms in cutaneous malignancies, depending on daily lifestyle. Therefore, other daily lifestyle factors might also be involved in the pathogenesis of cutaneous malignancies. Daily lifestyles are changing overtime. Further investigation of the detailed mechanisms of the development of cutaneous malignancies is desired in order to provide more clarity.

Author Contributions: Y.S. and M.N. wrote and revised manuscript. All authors have read and agreed to the published version of the manuscript.

Funding: This research received no external funding.

Conflicts of Interest: The authors declare no conflict of interest.

\section{References}

1. Dainichi, T.; Kitoh, A.; Otsuka, A.; Nakajima, S.; Nomura, T.; Kaplan, D.H.; Kabashima, K. The epithelial immune microenvironment (EIME) in atopic dermatitis and psoriasis. Nat. Immunol. 2018, 19, 1286-1298. [CrossRef]

2. Sawada, Y.; Gallo, R.L. Role of Epigenetics in the Regulation of Immune Functions of the Skin. J. Investig. Dermatol. 2020. [CrossRef] 
3. Bernard, J.J.; Gallo, R.L.; Krutmann, J. Photoimmunology: How ultraviolet radiation affects the immune system. Nat. Rev. Immunol. 2019, 19, 688-701. [CrossRef]

4. Chehade, L.; Jaafar, Z.A.; El Masri, D.; Zmerly, H.; Kreidieh, D.; Tannir, H.; Itani, L.; El Ghoch, M. Lifestyle Modification in Rheumatoid Arthritis: Dietary and Physical Activity Recommendations Based on Evidence. Curr. Rheumatol. Rev. 2019, 15, 209-214. [CrossRef] [PubMed]

5. Rippe, J.M.; Angelopoulos, T.J. Lifestyle strategies for cardiovascular risk reduction. Curr. Atheroscler. Rep. 2014, 16, 444. [CrossRef]

6. Sawada, Y.; Saito-Sasaki, N.; Nakamura, M. Omega 3 Fatty Acid and Skin Diseases. Front. Immunol. 2020, 11, 623052. [CrossRef] [PubMed]

7. Egawa, G.; Kabashima, K. Skin as a peripheral lymphoid organ: Revisiting the concept of skin-associated lymphoid tissues. J. Investig. Dermatol. 2011, 131, 2178-2185. [CrossRef] [PubMed]

8. Kabashima, K.; Honda, T.; Ginhoux, F.; Egawa, G. The immunological anatomy of the skin. Nat. Rev. Immunol. 2019, 19, 19-30. [CrossRef]

9. Broggi, G.; Verzì, A.E.; Caltabiano, R.; Micali, G.; Lacarrubba, F. Correlation Between In Vivo Reflectance Confocal Microscopy and Horizontal Histopathology in Skin Cancer: A Review. Front. Oncol. 2021, 11, 653140. [CrossRef]

10. Broggi, G.; Lacarrubba, F.; Verzì, A.E.; Micali, G.; Caltabiano, R. Confocal microscopy features of patch-stage mycosis fungoides and their correlation with horizontal histopathological sections. A case series. J. Cutan. Pathol. 2019, 46, 163-165. [CrossRef]

11. Broggi, G.; Verzì, A.E.; Lacarrubba, F.; Caltabiano, R.; Di Natale, A.; Micali, G. Correlation between reflectance confocal microscopy features and horizontal histopathology in cutaneous squamous cell carcinoma in situ: A case series. J. Cutan. Pathol. 2020, 47, 777-780. [CrossRef] [PubMed]

12. Watson, M.; Holman, D.M.; Maguire-Eisen, M. Ultraviolet Radiation Exposure and Its Impact on Skin Cancer Risk. Semin. Oncol. Nurs. 2016, 32, 241-254. [CrossRef]

13. Jenkins, R.W.; Fisher, D.E. Treatment of Advanced Melanoma in 2020 and Beyond. J. Invest. Dermatol. 2020. [CrossRef]

14. Simiczyjew, A.; Dratkiewicz, E.; Mazurkiewicz, J.; Ziętek, M.; Matkowski, R.; Nowak, D. The Influence of Tumor Microenvironment on Immune Escape of Melanoma. Int. J. Mol. Sci. 2020, 21, 8359. [CrossRef]

15. Sullivan, R.J.; Fisher, D.E. Understanding the biology of melanoma and therapeutic implications. Hematol. Oncol. Clin. N. Am. 2014, 28, 437-453. [CrossRef] [PubMed]

16. Yaman, B.; Akalin, T.; Kandiloğlu, G. Clinicopathological characteristics and mutation profiling in primary cutaneous melanoma. Am. J. Dermatopathol. 2015, 37, 389-397. [CrossRef] [PubMed]

17. Genomic Classification of Cutaneous Melanoma. Cell 2015, 161, 1681-1696. [CrossRef] [PubMed]

18. Hauschild, A.; Grob, J.J.; Demidov, L.V.; Jouary, T.; Gutzmer, R.; Millward, M.; Rutkowski, P.; Blank, C.U.; Miller, W.H., Jr.; Kaempgen, E.; et al. Dabrafenib in BRAF-mutated metastatic melanoma: A multicentre, open-label, phase 3 randomised controlled trial. Lancet 2012, 380, 358-365. [CrossRef]

19. Ottaviano, M.; Giunta, E.F.; Tortora, M.; Curvietto, M.; Attademo, L.; Bosso, D.; Cardalesi, C.; Rosanova, M.; De Placido, P.; Pietroluongo, E.; et al. BRAF Gene and Melanoma: Back to the Future. Int. J. Mol. Sci. 2021, 22, 3474. [CrossRef]

20. Peyssonnaux, C.; Eychène, A. The Raf/MEK/ERK pathway: New concepts of activation. Biol. Cell 2001, 93, 53-62. [CrossRef]

21. Morrison, D.K. MAP kinase pathways. Cold Spring Harb. Perspect. Biol. 2012, 4, a011254. [CrossRef]

22. Davies, H.; Bignell, G.R.; Cox, C.; Stephens, P.; Edkins, S.; Clegg, S.; Teague, J.; Woffendin, H.; Garnett, M.J.; Bottomley, W.; et al. Mutations of the BRAF gene in human cancer. Nature 2002, 417, 949-954. [CrossRef]

23. Wan, P.T.; Garnett, M.J.; Roe, S.M.; Lee, S.; Niculescu-Duvaz, D.; Good, V.M.; Jones, C.M.; Marshall, C.J.; Springer, C.J.; Barford, D.; et al. Mechanism of activation of the RAF-ERK signaling pathway by oncogenic mutations of B-RAF. Cell 2004, 116, 855-867. [CrossRef]

24. Long, G.V.; Menzies, A.M.; Nagrial, A.M.; Haydu, L.E.; Hamilton, A.L.; Mann, G.J.; Hughes, T.M.; Thompson, J.F.; Scolyer, R.A.; Kefford, R.F. Prognostic and clinicopathologic associations of oncogenic BRAF in metastatic melanoma. J. Clin. Oncol. Off. J. Am. Soc. Clin. Oncol. 2011, 29, 1239-1246. [CrossRef] [PubMed]

25. Hayward, N.K.; Wilmott, J.S.; Waddell, N.; Johansson, P.A.; Field, M.A.; Nones, K.; Patch, A.M.; Kakavand, H.; Alexandrov, L.B.; Burke, H.; et al. Whole-genome landscapes of major melanoma subtypes. Nature 2017, 545, 175-180. [CrossRef]

26. Beadling, C.; Jacobson-Dunlop, E.; Hodi, F.S.; Le, C.; Warrick, A.; Patterson, J.; Town, A.; Harlow, A.; Cruz, F., 3rd; Azar, S.; et al. KIT gene mutations and copy number in melanoma subtypes. Clin. Cancer Res. Off. J. Am. Assoc. Cancer Res. 2008, 14, 6821-6828. [CrossRef]

27. Curtin, J.A.; Busam, K.; Pinkel, D.; Bastian, B.C. Somatic activation of KIT in distinct subtypes of melanoma. J. Clin. Oncol. Off. J. Am. Soc. Clin. Oncol. 2006, 24, 4340-4346. [CrossRef] [PubMed]

28. Orlow, I.; Begg, C.B.; Cotignola, J.; Roy, P.; Hummer, A.J.; Clas, B.A.; Mujumdar, U.; Canchola, R.; Armstrong, B.K.; Kricker, A.; et al. CDKN2A germline mutations in individuals with cutaneous malignant melanoma. J. Investig. Dermatol. 2007, 127, 1234-1243. [CrossRef]

29. Spain, L.; Diem, S.; Larkin, J. Management of toxicities of immune checkpoint inhibitors. Cancer Treat. Rev. 2016, 44, 51-60. [CrossRef] 
30. Delanoy, N.; Michot, J.M.; Comont, T.; Kramkimel, N.; Lazarovici, J.; Dupont, R.; Champiat, S.; Chahine, C.; Robert, C.; Herbaux, C.; et al. Haematological immune-related adverse events induced by anti-PD-1 or anti-PD-L1 immunotherapy: A descriptive observational study. Lancet Haematol. 2019, 6, e48-e57. [CrossRef]

31. Oda, T.; Sawada, Y.; Okada, E.; Yamaguchi, T.; Ohmori, S.; Haruyama, S.; Yoshioka, M.; Nakamura, M. Hypopituitarism and hypothyroidism following atrioventricular block during nivolumab treatment. J. Dermatol. 2017, 44, e144-e145. [CrossRef]

32. Zimmer, L.; Livingstone, E.; Hassel, J.C.; Fluck, M.; Eigentler, T.; Loquai, C.; Haferkamp, S.; Gutzmer, R.; Meier, F.; Mohr, P.; et al. Adjuvant nivolumab plus ipilimumab or nivolumab monotherapy versus placebo in patients with resected stage IV melanoma with no evidence of disease (IMMUNED): A randomised, double-blind, placebo-controlled, phase 2 trial. Lancet 2020, 395, 1558-1568. [CrossRef]

33. Saito, R.; Sawada, Y.; Nakamura, M. Immune Profile Analysis in Peripheral Blood and Tumor in Patients with Malignant Melanoma. Int. J. Mol. Sci. 2021, 22, 1957. [CrossRef] [PubMed]

34. Mashima, E.; Inoue, A.; Sakuragi, Y.; Yamaguchi, T.; Sasaki, N.; Hara, Y.; Omoto, D.; Ohmori, S.; Haruyama, S.; Sawada, Y.; et al. Nivolumab in the treatment of malignant melanoma: Review of the literature. Oncotargets Ther. 2015, 8, $2045-2051$.

35. Saito, R.; Sawada, Y.; Saito-Sasaki, N.; Yamamoto, K.; Yoshioka, H.; Ohmori, S.; Yoshioka, M.; Okada, E.; Nakamura, M. Profile fluctuation of peripheral blood in advanced melanoma patients treated with nivolumab. J. Dermatol. 2018, 45, 1452-1455. [CrossRef] [PubMed]

36. Nonomura, Y.; Otsuka, A.; Nakashima, C.; Seidel, J.A.; Kitoh, A.; Dainichi, T.; Nakajima, S.; Sawada, Y.; Matsushita, S.; Aoki, M.; et al. Peripheral blood Th9 cells are a possible pharmacodynamic biomarker of nivolumab treatment efficacy in metastatic melanoma patients. Oncoimmunology 2016, 5, e1248327. [CrossRef]

37. Lomas, A.; Leonardi-Bee, J.; Bath-Hextall, F. A systematic review of worldwide incidence of nonmelanoma skin cancer. Br. J. Dermatol. 2012, 166, 1069-1080. [CrossRef] [PubMed]

38. Corchado-Cobos, R.; García-Sancha, N.; González-Sarmiento, R.; Pérez-Losada, J.; Cañueto, J. Cutaneous Squamous Cell Carcinoma: From Biology to Therapy. Int. J. Mol. Sci. 2020, 21, 2956. [CrossRef]

39. Burton, K.A.; Ashack, K.A.; Khachemoune, A. Cutaneous Squamous Cell Carcinoma: A Review of High-Risk and Metastatic Disease. Am. J. Clin. Dermatol. 2016, 17, 491-508. [CrossRef]

40. Claveau, J.; Archambault, J.; Ernst, D.S.; Giacomantonio, C.; Limacher, J.J.; Murray, C.; Parent, F.; Zloty, D. Multidisciplinary management of locally advanced and metastatic cutaneous squamous cell carcinoma. Curr. Oncol. 2020, 27, e399-e407. [CrossRef]

41. Li, G.; Ho, V.C.; Berean, K.; Tron, V.A. Ultraviolet radiation induction of squamous cell carcinomas in p53 transgenic mice. Cancer Res. 1995, 55, 2070-2074.

42. Becker, J.C.; Zur Hausen, A. Cells of origin in skin cancer. J. Investig. Dermatol. 2014, 134, 2491-2493. [CrossRef]

43. Sekulic, A.; Migden, M.R.; Oro, A.E.; Dirix, L.; Lewis, K.D.; Hainsworth, J.D.; Solomon, J.A.; Yoo, S.; Arron, S.T.; Friedlander, P.A.; et al. Efficacy and safety of vismodegib in advanced basal-cell carcinoma. N. Engl. J. Med. 2012, 366, 2171-2179. [CrossRef] [PubMed]

44. Zhang, H.; Ping, X.L.; Lee, P.K.; Wu, X.L.; Yao, Y.J.; Zhang, M.J.; Silvers, D.N.; Ratner, D.; Malhotra, R.; Peacocke, M.; et al. Role of PTCH and p53 genes in early-onset basal cell carcinoma. Am. J. Pathol. 2001, 158, 381-385. [CrossRef]

45. Schmitt, J.; Haufe, E.; Trautmann, F.; Schulze, H.J.; Elsner, P.; Drexler, H.; Bauer, A.; Letzel, S.; John, S.M.; Fartasch, M.; et al. Is ultraviolet exposure acquired at work the most important risk factor for cutaneous squamous cell carcinoma? Results of the population-based case-control study FB-181. Br. J. Dermatol. 2018, 178, 462-472. [CrossRef] [PubMed]

46. Ouhtit, A.; Nakazawa, H.; Armstrong, B.K.; Kricker, A.; Tan, E.; Yamasaki, H.; English, D.R. UV-radiation-specific p53 mutation frequency in normal skin as a predictor of risk of basal cell carcinoma. J. Natl. Cancer Inst. 1998, 90, 523-531. [CrossRef] [PubMed]

47. Pipas, J.M.; Levine, A.J. Role of T antigen interactions with p53 in tumorigenesis. Semin. Cancer Biol. 2001, 11, 23-30. [CrossRef] [PubMed]

48. Sastre-Garau, X.; Peter, M.; Avril, M.F.; Laude, H.; Couturier, J.; Rozenberg, F.; Almeida, A.; Boitier, F.; Carlotti, A.; Couturaud, B.; et al. Merkel cell carcinoma of the skin: Pathological and molecular evidence for a causative role of MCV in oncogenesis. J. Pathol. 2009, 218, 48-56. [CrossRef] [PubMed]

49. Shuda, M.; Feng, H.; Kwun, H.J.; Rosen, S.T.; Gjoerup, O.; Moore, P.S.; Chang, Y. T antigen mutations are a human tumor-specific signature for Merkel cell polyomavirus. Proc. Natl. Acad. Sci. USA 2008, 105, 16272-16277. [CrossRef]

50. Becker, J.C.; Stang, A.; DeCaprio, J.A.; Cerroni, L.; Lebbé, C.; Veness, M.; Nghiem, P. Merkel cell carcinoma. Nat. Rev. Dis. Primers 2017, 3, 17077. [CrossRef]

51. Hettwer, S.; Besic Gyenge, E.; Obermayer, B. Influence of cosmetic formulations on the skin's circadian clock. Int. J. Cosmet. Sci. 2020, 42, 313-319. [CrossRef] [PubMed]

52. Ando, N.; Nakamura, Y.; Aoki, R.; Ishimaru, K.; Ogawa, H.; Okumura, K.; Shibata, S.; Shimada, S.; Nakao, A. Circadian Gene Clock Regulates Psoriasis-Like Skin Inflammation in Mice. J. Investig. Dermatol. 2015, 135, 3001-3008. [CrossRef] [PubMed]

53. Schernhammer, E.S.; Razavi, P.; Li, T.Y.; Qureshi, A.A.; Han, J. Rotating night shifts and risk of skin cancer in the nurses' health study. J. Natl. Cancer Inst. 2011, 103, 602-606. [CrossRef]

54. Yousef, E.; Mitwally, N.; Noufal, N.; Tahir, M.R. Shift work and risk of skin cancer: A systematic review and meta-analysis. Sci. Rep. 2020, 10, 2012. [CrossRef] 
55. Aiello, I.; Fedele, M.L.M.; Román, F.; Marpegan, L.; Caldart, C.; Chiesa, J.J.; Golombek, D.A.; Finkielstein, C.V.; Paladino, N. Circadian disruption promotes tumor-immune microenvironment remodeling favoring tumor cell proliferation. Sci. Adv. 2020, 6, eaaz4530. [CrossRef]

56. De Assis, L.V.; Moraes, M.N.; da Silveira Cruz-Machado, S.; Castrucci, A.M. The effect of white light on normal and malignant murine melanocytes: A link between opsins, clock genes, and melanogenesis. Biochim. Biophys. Acta 2016, 1863, 1119-1133. [CrossRef] [PubMed]

57. De Assis, L.V.M.; Moraes, M.N.; Magalhães-Marques, K.K.; Kinker, G.S.; da Silveira Cruz-Machado, S.; Castrucci, A.M.L. NonMetastatic Cutaneous Melanoma Induces Chronodisruption in Central and Peripheral Circadian Clocks. Int. J. Mol. Sci. 2018, 19, 1065. [CrossRef]

58. Lengyel, Z.; Lovig, C.; Kommedal, S.; Keszthelyi, R.; Szekeres, G.; Battyáni, Z.; Csernus, V.; Nagy, A.D. Altered expression patterns of clock gene mRNAs and clock proteins in human skin tumors. Tumour Biol. 2013, 34, 811-819. [CrossRef]

59. De Assis, L.V.M.; Kinker, G.S.; Moraes, M.N.; Markus, R.P.; Fernandes, P.A.; Castrucci, A.M.L. Expression of the Circadian Clock Gene BMAL1 Positively Correlates with Antitumor Immunity and Patient Survival in Metastatic Melanoma. Front. Oncol. 2018, 8 , 185. [CrossRef]

60. Kiessling, S.; Beaulieu-Laroche, L.; Blum, I.D.; Landgraf, D.; Welsh, D.K.; Storch, K.F.; Labrecque, N.; Cermakian, N. Enhancing circadian clock function in cancer cells inhibits tumor growth. BMC Biol. 2017, 15, 13. [CrossRef]

61. Hamilton, N.; Diaz-de-Cerio, N.; Whitmore, D. Impaired light detection of the circadian clock in a zebrafish melanoma model. Cell. Cycle 2015, 14, 1232-1241. [CrossRef] [PubMed]

62. Li, H.X.; Fu, X.J.; Yang, K.; Chen, D.; Tang, H.; Zhao, Q. The clock gene PER1 suppresses expression of tumor-related genes in human oral squamous cell carcinoma. Oncotarget 2016, 7, 20574-20583. [CrossRef]

63. Zhao, N.; Yang, K.; Yang, G.; Chen, D.; Tang, H.; Zhao, D.; Zhao, C. Aberrant expression of clock gene period1 and its correlations with the growth, proliferation and metastasis of buccal squamous cell carcinoma. PLoS ONE 2013, 8, e55894. [CrossRef] [PubMed]

64. Yang, G.; Yang, Y.; Tang, H.; Yang, K. Loss of the clock gene Per1 promotes oral squamous cell carcinoma progression via the AKT/mTOR pathway. Cancer Sci. 2020, 111, 1542-1554. [CrossRef]

65. Chen, R.; Yang, K.; Zhao, N.B.; Zhao, D.; Chen, D.; Zhao, C.R.; Tang, H. Abnormal expression of PER1 circadian-clock gene in oral squamous cell carcinoma. Oncotargets Ther. 2012, 5, 403-407.

66. Hsu, C.M.; Lin, S.F.; Lu, C.T.; Lin, P.M.; Yang, M.Y. Altered expression of circadian clock genes in head and neck squamous cell carcinoma. Tumour Biol. 2012, 33, 149-155. [CrossRef]

67. Fu, X.J.; Li, H.X.; Yang, K.; Chen, D.; Tang, H. The important tumor suppressor role of PER1 in regulating the cyclin-CDK-CKI network in SCC15 human oral squamous cell carcinoma cells. Oncotargets Ther. 2016, 9, 2237-2245.

68. Zhao, Q.; Zheng, G.; Yang, K.; Ao, Y.R.; Su, X.L.; Li, Y.; Lv, X.Q. The clock gene PER1 plays an important role in regulating the clock gene network in human oral squamous cell carcinoma cells. Oncotargets 2016, 7, 70290-70302. [CrossRef] [PubMed]

69. Janich, P.; Pascual, G.; Merlos-Suárez, A.; Batlle, E.; Ripperger, J.; Albrecht, U.; Cheng, H.Y.; Obrietan, K.; Di Croce, L.; Benitah, S.A. The circadian molecular clock creates epidermal stem cell heterogeneity. Nature 2011, 480, 209-214. [CrossRef]

70. Xiong, H.; Yang, Y.; Yang, K.; Zhao, D.; Tang, H.; Ran, X. Loss of the clock gene PER2 is associated with cancer development and altered expression of important tumor-related genes in oral cancer. Int. J. Oncol. 2018, 52, 279-287. [CrossRef]

71. Liu, H.; Gong, X.; Yang, K. Overexpression of the clock gene Per2 suppresses oral squamous cell carcinoma progression by activating autophagy via the PI3K/AKT/mTOR pathway. J. Cancer 2020, 11, 3655-3666. [CrossRef]

72. Wang, Q.; Ao, Y.; Yang, K.; Tang, H.; Chen, D. Circadian clock gene Per2 plays an important role in cell proliferation, apoptosis and cell cycle progression in human oral squamous cell carcinoma. Oncol. Rep. 2016, 35, 3387-3394. [CrossRef]

73. Robb, C.T.; McSorley, H.J.; Lee, J.; Aoki, T.; Yu, C.; Crittenden, S.; Astier, A.; Felton, J.M.; Parkinson, N.; Ayele, A.; et al. Prostaglandin E(2) stimulates adaptive IL-22 production and promotes allergic contact dermatitis. J. Allergy Clin. Immunol. 2018, 141, 152-162. [CrossRef]

74. Su, X.; Chen, D.; Yang, K.; Zhao, Q.; Zhao, D.; Lv, X.; Ao, Y. The circadian clock gene PER2 plays an important role in tumor suppression through regulating tumor-associated genes in human oral squamous cell carcinoma. Oncol. Rep. 2017, 38, 472-480. [CrossRef] [PubMed]

75. Tang, Q.; Cheng, B.; Xie, M.; Chen, Y.; Zhao, J.; Zhou, X.; Chen, L. Circadian Clock Gene Bmal1 Inhibits Tumorigenesis and Increases Paclitaxel Sensitivity in Tongue Squamous Cell Carcinoma. Cancer Res. 2017, 77, 532-544. [CrossRef] [PubMed]

76. Godlaski, T.M. Holy smoke: Tobacco use among native American tribes in North America. Subst. Use Misuse 2013, 48, 1-8. [CrossRef]

77. Hackshaw, A.; Morris, J.K.; Boniface, S.; Tang, J.L.; Milenković, D. Low cigarette consumption and risk of coronary heart disease and stroke: Meta-analysis of 141 cohort studies in 55 study reports. BMJ 2018, 360, j5855. [CrossRef]

78. Tromp, J.; Paniagua, S.M.A.; Lau, E.S.; Allen, N.B.; Blaha, M.J.; Gansevoort, R.T.; Hillege, H.L.; Lee, D.E.; Levy, D.; Ramachandran, V.S.; et al. Age dependent associations of risk factors with heart failure: Pooled population based cohort study. BMJ 2021, 372, n461. [CrossRef]

79. Parsons, A.; Daley, A.; Begh, R.; Aveyard, P. Influence of smoking cessation after diagnosis of early stage lung cancer on prognosis: Systematic review of observational studies with meta-analysis. BMJ 2010, 340, b5569. [CrossRef]

80. Sondermeijer, L.; Lamboo, L.G.E.; de Waal, A.C.; Galesloot, T.E.; Kiemeney, L.; van Rossum, M.; Aben, K.H. Cigarette Smoking and the Risk of Cutaneous Melanoma: A Case-Control Study. Dermatology 2020, 236, 228-236. [CrossRef] [PubMed] 
81. Dusingize, J.C.; Olsen, C.M.; Pandeya, N.; Thompson, B.S.; Webb, P.M.; Green, A.C.; Neale, R.E.; Whiteman, D.C. Smoking and Cutaneous Melanoma: Findings from the QSkin Sun and Health Cohort Study. Cancer Epidemiol. Biomark. Prev. 2018, $27,874-881$. [CrossRef] [PubMed]

82. Gibson, J.A.G.; Dobbs, T.D.; Griffiths, R.; Song, J.; Akbari, A.; Whitaker, S.; Watkins, A.; Langan, S.M.; Hutchings, H.A.; Lyons, R.A.; et al. The association of smoking and socioeconomic status on cutaneous melanoma: A population-based, data-linkage, case-control study. Br. J. Dermatol. 2020, 182, 1136-1147. [CrossRef] [PubMed]

83. Tejera-Vaquerizo, A.; Descalzo-Gallego, M.A.; Traves, V.; Requena, C.; Bolumar, I.; Pla, A.; Nagore, E. No association between smoking and sentinel lymph node metastasis and survival in cutaneous melanoma. J. Eur. Acad. Dermatol. Venereol. 2019, 33, 2283-2290. [CrossRef]

84. Jones, M.S.; Jones, P.C.; Stern, S.L.; Elashoff, D.; Hoon, D.S.B.; Thompson, J.; Mozzillo, N.; Nieweg, O.E.; Noyes, D.; Hoekstra, H.J.; et al. The Impact of Smoking on Sentinel Node Metastasis of Primary Cutaneous Melanoma. Ann. Surg. Oncol. 2017, 24, 2089-2094. [CrossRef] [PubMed]

85. De Hertog, S.A.; Wensveen, C.A.; Bastiaens, M.T.; Kielich, C.J.; Berkhout, M.J.; Westendorp, R.G.; Vermeer, B.J.; Bouwes Bavinck, J.N. Relation between smoking and skin cancer. J. Clin. Oncol. Off. J. Am. Soc. Clin. Oncol. 2001, 19, 231-238. [CrossRef]

86. Leonardi-Bee, J.; Ellison, T.; Bath-Hextall, F. Lifestyle factors of smoking, BMI and alcohol on the risk of Non-Melanoma Skin Cancer in adults: A systematic review. JBI Libr. Syst. Rev. 2012, 10, 352-398. [CrossRef]

87. Pirie, K.; Beral, V.; Heath, A.K.; Green, J.; Reeves, G.K.; Peto, R.; McBride, P.; Olsen, C.M.; Green, A.C. Heterogeneous relationships of squamous and basal cell carcinomas of the skin with smoking: The UK Million Women Study and meta-analysis of prospective studies. Br. J. Cancer 2018, 119, 114-120. [CrossRef]

88. Odenbro, A.; Bellocco, R.; Boffetta, P.; Lindelöf, B.; Adami, J. Tobacco smoking, snuff dipping and the risk of cutaneous squamous cell carcinoma: A nationwide cohort study in Sweden. Br. J. Cancer 2005, 92, 1326-1328. [CrossRef]

89. McBride, P.; Olsen, C.M.; Green, A.C. Tobacco smoking and cutaneous squamous cell carcinoma: A 16-year longitudinal population-based study. Cancer Epidemiol. Biomark. Prev. 2011, 20, 1778-1783. [CrossRef]

90. Hughes, M.C.; Olsen, C.M.; Williams, G.M.; Green, A.C. A prospective study of cigarette smoking and basal cell carcinoma. Arch. Dermatol. Res. 2014, 306, 851-856. [CrossRef]

91. Song, F.; Qureshi, A.A.; Gao, X.; Li, T.; Han, J. Smoking and risk of skin cancer: A prospective analysis and a meta-analysis. Int. J. Epidemiol. 2012, 41, 1694-1705. [CrossRef] [PubMed]

92. Dusingize, J.C.; Olsen, C.M.; Pandeya, N.P.; Subramaniam, P.; Thompson, B.S.; Neale, R.E.; Green, A.C.; Whiteman, D.C. Cigarette Smoking and the Risks of Basal Cell Carcinoma and Squamous Cell Carcinoma. J. Investig. Dermatol. 2017, 137, 1700-1708. [CrossRef]

93. Arafa, A.; Mostafa, A.; Navarini, A.A.; Dong, J.Y. The association between smoking and risk of skin cancer: A meta-analysis of cohort studies. Cancer Causes Control 2020, 31, 787-794. [CrossRef]

94. Corona, R.; Dogliotti, E.; D’Errico, M.; Sera, F.; Iavarone, I.; Baliva, G.; Chinni, L.M.; Gobello, T.; Mazzanti, C.; Puddu, P.; et al. Risk factors for basal cell carcinoma in a Mediterranean population: Role of recreational sun exposure early in life. Arch. Dermatol. 2001, 137, 1162-1168. [CrossRef]

95. Karagas, M.R.; Stukel, T.A.; Greenberg, E.R.; Baron, J.A.; Mott, L.A.; Stern, R.S. Risk of subsequent basal cell carcinoma and squamous cell carcinoma of the skin among patients with prior skin cancer. Skin Cancer Prevention Study Group. JAMA 1992, 267, 3305-3310. [CrossRef]

96. Freedman, D.M.; Sigurdson, A.; Doody, M.M.; Mabuchi, K.; Linet, M.S. Risk of basal cell carcinoma in relation to alcohol intake and smoking. Cancer Epidemiol. Biomark. Prev. 2003, 12, 1540-1543.

97. Gon, A.; Minelli, L. Risk factors for basal cell carcinoma in a southern Brazilian population: A case-control study. Int. J. Dermatol. 2011, 50, 1286-1290. [CrossRef]

98. Leonardi-Bee, J.; Ellison, T.; Bath-Hextall, F. Smoking and the risk of nonmelanoma skin cancer: Systematic review and metaanalysis. Arch. Dermatol. 2012, 148, 939-946. [CrossRef] [PubMed]

99. Erbagci, Z.; Erkiliç, S. Can smoking and/or occupational UV exposure have any role in the development of the morpheaform basal cell carcinoma? A critical role for peritumoral mast cells. Int. J. Dermatol. 2002, 41, 275-278. [CrossRef]

100. Bain, C.; Green, A.; Siskind, V.; Alexander, J.; Harvey, P. Diet and melanoma. An exploratory case-control study. Ann. Epidemiol. 1993, 3, 235-238.

101. Kirkpatrick, C.S.; White, E.; Lee, J.A. Case-control study of malignant melanoma in Washington State. II. Diet, alcohol, and obesity. Am. J. Epidemiol. 1994, 139, 869-880. [CrossRef] [PubMed]

102. Freedman, D.M.; Sigurdson, A.; Doody, M.M.; Rao, R.S.; Linet, M.S. Risk of melanoma in relation to smoking, alcohol intake, and other factors in a large occupational cohort. Cancer Causes Control 2003, 14, 847-857. [CrossRef] [PubMed]

103. Millen, A.E.; Tucker, M.A.; Hartge, P.; Halpern, A.; Elder, D.E.; Guerry, D.; Holly, E.A.; Sagebiel, R.W.; Potischman, N. Diet and melanoma in a case-control study. Cancer Epidemiol. Biomark. Prev. 2004, 13, 1042-1051.

104. Le Marchand, L.; Saltzman, B.S.; Hankin, J.H.; Wilkens, L.R.; Franke, A.A.; Morris, S.J.; Kolonel, L.N. Sun exposure, diet, and melanoma in Hawaii Caucasians. Am. J. Epidemiol. 2006, 164, 232-245. [CrossRef] [PubMed]

105. Kubo, J.T.; Henderson, M.T.; Desai, M.; Wactawski-Wende, J.; Stefanick, M.L.; Tang, J.Y. Alcohol consumption and risk of melanoma and non-melanoma skin cancer in the Women's Health Initiative. Cancer Causes Control 2014, 25, 1-10. [CrossRef] [PubMed] 
106. Osterlind, A.; Tucker, M.A.; Stone, B.J.; Jensen, O.M. The Danish case-control study of cutaneous malignant melanoma. IV. No association with nutritional factors, alcohol, smoking or hair dyes. Int. J. Cancer 1988, 42, 825-828.

107. Osterlind, A. Malignant melanoma in Denmark. Occurrence and risk factors. Acta Oncol. 1990, 29, 833-854. [CrossRef]

108. Naldi, L.; Gallus, S.; Tavani, A.; Imberti, G.L.; La Vecchia, C. Risk of melanoma and vitamin A, coffee and alcohol: A case-control study from Italy. Eur. J. Cancer Prev. 2004, 13, 503-508. [CrossRef]

109. Rota, M.; Pasquali, E.; Bellocco, R.; Bagnardi, V.; Scotti, L.; Islami, F.; Negri, E.; Boffetta, P.; Pelucchi, C.; Corrao, G.; et al. Alcohol drinking and cutaneous melanoma risk: A systematic review and dose-risk meta-analysis. Br. J. Dermatol. 2014, 170, 1021-1028. [CrossRef]

110. Fung, T.T.; Hunter, D.J.; Spiegelman, D.; Colditz, G.A.; Rimm, E.B.; Willett, W.C. Intake of alcohol and alcoholic beverages and the risk of basal cell carcinoma of the skin. Cancer Epidemiol. Biomark. Prev. 2002, 11, 1119-1122.

111. Husein-Elahmed, H.; Aneiros-Fernandez, J.; Gutierrez-Salmerón, M.T.; Botella-Lopez, M.; Aneiros-Cachaza, J.; Naranjo-Sintes, R. Alcohol intake and risk of aggressive histological basal cell carcinoma: A case-control study. Eur. J. Dermatol. 2012, 22, 525-530. [CrossRef]

112. Wu, S.; Li, W.Q.; Qureshi, A.A.; Cho, E. Alcohol consumption and risk of cutaneous basal cell carcinoma in women and men: 3 prospective cohort studies. Am. J. Clin. Nutr. 2015, 102, 1158-1166. [CrossRef]

113. Sahl, W.J.; Glore, S.; Garrison, P.; Oakleaf, K.; Johnson, S.D. Basal cell carcinoma and lifestyle characteristics. Int. J. Dermatol. 1995, 34, 398-402. [CrossRef] [PubMed]

114. Yen, H.; Dhana, A.; Okhovat, J.P.; Qureshi, A.; Keum, N.; Cho, E. Alcohol intake and risk of nonmelanoma skin cancer: A systematic review and dose-response meta-analysis. Br. J. Dermatol. 2017, 177, 696-707. [CrossRef] [PubMed]

115. Slavin, J.L. Dietary fiber and body weight. Nutrition 2005, 21, 411-418. [CrossRef]

116. Rose, D.P. Dietary fiber and breast cancer. Nutr. Cancer 1990, 13, 1-8. [CrossRef] [PubMed]

117. De Waure, C.; Quaranta, G.; Gualano, M.R.; Cadeddu, C.; Jovic-Vranes, A.; Djikanovic, B.; La Torre, G.; Ricciardi, W. Systematic review of studies investigating the association between dietary habits and cutaneous malignant melanoma. Public Health 2015, 129, 1099-1113. [CrossRef] [PubMed]

118. Sun, W.; Rice, M.S.; Park, M.K.; Chun, O.K.; Melough, M.M.; Nan, H.; Willett, W.C.; Li, W.Q.; Qureshi, A.A.; Cho, E. Intake of Furocoumarins and Risk of Skin Cancer in 2 Prospective US Cohort Studies. J. Nutr. 2020, 150, 1535-1544. [CrossRef]

119. Shin, J.; Song, I.S.; Pak, J.H.; Jang, S.W. Upregulation of annexin A1 expression by butyrate in human melanoma cells induces invasion by inhibiting E-cadherin expression. Tumour Biol. 2016, 37, 14577-14584. [CrossRef] [PubMed]

120. Mahamat-Saleh, Y.; Cervenka, I.; Al-Rahmoun, M.; Mancini, F.R.; Severi, G.; Ghiasvand, R.; Veierod, M.B.; Caini, S.; Palli, D.; Botteri, E.; et al. Citrus intake and risk of skin cancer in the European Prospective Investigation into Cancer and Nutrition cohort (EPIC). Eur. J. Epidemiol. 2020, 35, 1057-1067. [CrossRef]

121. Wu, S.; Cho, E.; Feskanich, D.; Li, W.Q.; Sun, Q.; Han, J.; Qureshi, A.A. Citrus consumption and risk of basal cell carcinoma and squamous cell carcinoma of the skin. Carcinogenesis 2015, 36, 1162-1168. [CrossRef] [PubMed]

122. Hakim, I.A.; Harris, R.B.; Ritenbaugh, C. Citrus peel use is associated with reduced risk of squamous cell carcinoma of the skin. Nutr. Cancer 2000, 37, 161-168. [CrossRef]

123. Lahmann, P.H.; Ibiebele, T.I.; Webb, P.M.; Nagle, C.M.; Whiteman, D.C. A case-control study of glycemic index, glycemic load and dietary fiber intake and risk of adenocarcinomas and squamous cell carcinomas of the esophagus: The Australian Cancer Study. BMC Cancer 2014, 14, 877. [CrossRef]

124. Skowron, F.; Bérard, F.; Balme, B.; Maucort-Boulch, D. Role of obesity on the thickness of primary cutaneous melanoma. J. Eur. Acad. Dermatol. Venereol. 2015, 29, 262-269. [CrossRef]

125. Taube, M.; Peltonen, M.; Sjöholm, K.; Anveden, Å.; Andersson-Assarsson, J.C.; Jacobson, P.; Svensson, P.A.; Bergo, M.O.; Carlsson, L.M.S. Association of Bariatric Surgery with Skin Cancer Incidence in Adults with Obesity: A Nonrandomized Controlled Trial. JAMA Dermatol. 2020, 156, 38-43. [CrossRef]

126. Præstegaard, C.; Kjær, S.K.; Christensen, J.; Tjønneland, A.; Halkjær, J.; Jensen, A. Obesity and risks for malignant melanoma and non-melanoma skin cancer: Results from a large Danish prospective cohort study. J. Investig. Dermatol. 2015, 135, 901-904. [CrossRef]

127. Pothiawala, S.; Qureshi, A.A.; Li, Y.; Han, J. Obesity and the incidence of skin cancer in US Caucasians. Cancer Causes Control 2012, 23, 717-726. [CrossRef] [PubMed]

128. De Giorgi, V.; Gori, A.; Savarese, I.; D’Errico, A.; Scarfi, F.; Papi, F.; Maio, V.; Covarelli, P.; Massi, D.; Gandini, S. Role of BMI and hormone therapy in melanoma risk: A case-control study. J. Cancer Res. Clin. Oncol. 2017, 143, 1191-1197. [CrossRef]

129. Dennis, L.K.; Lowe, J.B.; Lynch, C.F.; Alavanja, M.C. Cutaneous melanoma and obesity in the Agricultural Health Study. Ann. Epidemiol. 2008, 18, 214-221. [CrossRef] [PubMed]

130. Ueharaguchi, Y.; Honda, T.; Kusuba, N.; Hanakawa, S.; Adachi, A.; Sawada, Y.; Otsuka, A.; Kitoh, A.; Dainichi, T.; Egawa, G.; et al Thromboxane A(2) facilitates IL-17A production from $\mathrm{V} \gamma 4(+) \gamma \delta \mathrm{T}$ cells and promotes psoriatic dermatitis in mice. J. Allergy Clin. Immunol. 2018, 142, 680-683.e2. [CrossRef]

131. Honda, T.; Matsuoka, T.; Ueta, M.; Kabashima, K.; Miyachi, Y.; Narumiya, S. Prostaglandin E(2)-EP(3) signaling suppresses skin inflammation in murine contact hypersensitivity. J. Allergy Clin. Immunol. 2009, 124, 809-818.e2. [CrossRef] [PubMed] 
132. Sawada, Y.; Honda, T.; Nakamizo, S.; Nakajima, S.; Nonomura, Y.; Otsuka, A.; Egawa, G.; Yoshimoto, T.; Nakamura, M.; Narumiya, S.; et al. Prostaglandin E(2) (PGE(2))-EP2 signaling negatively regulates murine atopic dermatitis-like skin inflammation by suppressing thymic stromal lymphopoietin expression. J. Allergy Clin. Immunol. 2019, 144, 1265-1273.e9. [CrossRef] [PubMed]

133. Mahamat-Saleh, Y.; Hughes, M.C.B.; Miura, K.; Malt, M.K.; von Schuckmann, L.; Khosrotehrani, K.; Smithers, B.M.; Green, A.C. Patterns of Omega-3 and Omega-6 Fatty Acid Dietary Intake and Melanoma Thickness at Diagnosis. Cancer Epidemiol. Biomark. Prev. 2020, 29, 1647-1653. [CrossRef]

134. Saito-Sasaki, N.; Sawada, Y.; Mashima, E.; Yamaguchi, T.; Ohmori, S.; Yoshioka, H.; Haruyama, S.; Okada, E.; Nakamura, M. Maresin-1 suppresses imiquimod-induced skin inflammation by regulating IL-23 receptor expression. Sci. Rep. 2018, 8, 5522. [CrossRef]

135. Sawada, Y.; Honda, T.; Nakamizo, S.; Otsuka, A.; Ogawa, N.; Kobayashi, Y.; Nakamura, M.; Kabashima, K. Resolvin E1 attenuates murine psoriatic dermatitis. Sci. Rep. 2018, 8, 11873. [CrossRef]

136. Sawada, Y.; Honda, T.; Hanakawa, S.; Nakamizo, S.; Murata, T.; Ueharaguchi-Tanada, Y.; Ono, S.; Amano, W.; Nakajima, S.; Egawa, G.; et al. Resolvin E1 inhibits dendritic cell migration in the skin and attenuates contact hypersensitivity responses. J. Exp. Med. 2015, 212, 1921-1930. [CrossRef]

137. Park, M.K.; Li, W.Q.; Qureshi, A.A.; Cho, E. Fat Intake and Risk of Skin Cancer in U.S. Adults. Cancer Epidemiol. Biomark. Prev. 2018, 27, 776-782. [CrossRef]

138. Noel, S.E.; Stoneham, A.C.; Olsen, C.M.; Rhodes, L.E.; Green, A.C. Consumption of omega-3 fatty acids and the risk of skin cancers: A systematic review and meta-analysis. Int. J. Cancer 2014, 135, 149-156. [CrossRef]

139. Xia, S.; Lu, Y.; Wang, J.; He, C.; Hong, S.; Serhan, C.N.; Kang, J.X. Melanoma growth is reduced in fat-1 transgenic mice: Impact of omega-6/omega-3 essential fatty acids. Proc. Natl. Acad. Sci. USA 2006, 103, 12499-12504. [CrossRef]

140. Albino, A.P.; Juan, G.; Traganos, F.; Reinhart, L.; Connolly, J.; Rose, D.P.; Darzynkiewicz, Z. Cell cycle arrest and apoptosis of melanoma cells by docosahexaenoic acid: Association with decreased pRb phosphorylation. Cancer Res. 2000, 60, 4139-4145.

141. Serini, S.; Zinzi, A.; Ottes Vasconcelos, R.; Fasano, E.; Riillo, M.G.; Celleno, L.; Trombino, S.; Cassano, R.; Calviello, G. Role of $\beta$-catenin signaling in the anti-invasive effect of the omega-3 fatty acid DHA in human melanoma cells. J. Dermatol. Sci. 2016, 84, 149-159. [CrossRef] [PubMed]

142. Denkins, Y.; Kempf, D.; Ferniz, M.; Nileshwar, S.; Marchetti, D. Role of omega-3 polyunsaturated fatty acids on cyclooxygenase-2 metabolism in brain-metastatic melanoma. J. Lipid. Res. 2005, 46, 1278-1284. [CrossRef] [PubMed]

143. Yin, X.; Yu, X.W.; Zhu, P.; Zhang, Y.M.; Zhang, X.H.; Wang, F.; Zhang, J.J.; Yan, W.; Xi, Y.; Wan, J.B.; et al. Endogenously synthesized n-3 fatty acids in fat- 1 transgenic mice prevent melanoma progression by increasing E-cadherin expression and inhibiting $\beta$-catenin signaling. Mol. Med. Rep. 2016, 14, 3476-3484. [CrossRef] [PubMed]

144. Ottes Vasconcelos, R.; Serini, S.; de Souza Votto, A.P.; Santos Trindade, G.; Fanali, C.; Sgambato, A.; Calviello, G. Combination of $\omega-3$ fatty acids and cisplatin as a potential alternative strategy for personalized therapy of metastatic melanoma: An in-vitro study. Melanoma Res. 2019, 29, 270-280. [CrossRef] [PubMed]

145. Li, J.; Chen, C.Y.; Arita, M.; Kim, K.; Li, X.; Zhang, H.; Kang, J.X. An omega-3 polyunsaturated fatty acid derivative, 18-HEPE, protects against CXCR4-associated melanoma metastasis. Carcinogenesis 2018, 39, 1380-1388. [CrossRef]

146. Bachi, A.L.; Kim, F.J.; Nonogaki, S.; Carneiro, C.R.; Lopes, J.D.; Jasiulionis, M.G.; Correa, M. Leukotriene B4 creates a favorable microenvironment for murine melanoma growth. Mol. Cancer Res. 2009, 7, 1417-1424. [CrossRef]

147. Sulciner, M.L.; Serhan, C.N.; Gilligan, M.M.; Mudge, D.K.; Chang, J.; Gartung, A.; Lehner, K.A.; Bielenberg, D.R.; Schmidt, B.; Dalli, J.; et al. Resolvins suppress tumor growth and enhance cancer therapy. J. Exp. Med. 2018, 215, 115-140. [CrossRef]

148. Miura, K.; Way, M.; Jiyad, Z.; Marquart, L.; Plasmeijer, E.I.; Campbell, S.; Isbel, N.; Fawcett, J.; Ferguson, L.E.; Davis, M.; et al. Omega-3 fatty acid intake and decreased risk of skin cancer in organ transplant recipients. Eur. J. Nutr. 2020, 9, 1-9. [CrossRef]

149. Wallingford, S.C.; van As, J.A.; Hughes, M.C.; Ibiebele, T.I.; Green, A.C.; van der Pols, J.C. Intake of omega-3 and omega-6 fatty acids and risk of basal and squamous cell carcinomas of the skin: A longitudinal community-based study in Australian adults. Nutr. Cancer 2012, 64, 982-990. [CrossRef]

150. Wallingford, S.C.; Hughes, M.C.; Green, A.C.; van der Pols, J.C. Plasma omega-3 and omega-6 concentrations and risk of cutaneous basal and squamous cell carcinomas in Australian adults. Cancer Epidemiol. Biomark. Prev. 2013, 22, 1900-1905. [CrossRef]

151. Rehman, K.; Mohd Amin, M.C.; Yuen, N.P.; Zulfakar, M.H. Immunomodulatory Effectiveness of Fish Oil and omega-3 Fatty Acids in Human Non-melanoma Skin Carcinoma Cells. J. Oleo Sci. 2016, 65, 217-224. [CrossRef]

152. Ye, Y.; Scheff, N.N.; Bernabé, D.; Salvo, E.; Ono, K.; Liu, C.; Veeramachaneni, R.; Viet, C.T.; Viet, D.T.; Dolan, J.C.; et al. Anti-cancer and analgesic effects of resolvin D2 in oral squamous cell carcinoma. Neuropharmacology 2018, 139, 182-193. [CrossRef]

153. Daneschvar, H.L.; Smetana, G.W.; Brindamour, L.; Bain, P.A.; Mukamal, K.J. Impact of Coffee Consumption on Physiological Markers of Cardiovascular Risk: A Systematic Review. Am. J. Med. 2020. [CrossRef]

154. Park, S.Y.; Freedman, N.D.; Haiman, C.A.; Le Marchand, L.; Wilkens, L.R.; Setiawan, V.W. Prospective Study of Coffee Consumption and Cancer Incidence in Non-White Populations. Cancer Epidemiol Biomark. Prev. 2018, 27, 928-935. [CrossRef] [PubMed]

155. Micek, A.; Godos, J.; Lafranconi, A.; Marranzano, M.; Pajak, A. Caffeinated and decaffeinated coffee consumption and melanoma risk: A dose-response meta-analysis of prospective cohort studies. Int. J. Food Sci. Nutr. 2018, 69, 417-426. [CrossRef] 
156. Loftfield, E.; Freedman, N.D.; Graubard, B.I.; Hollenbeck, A.R.; Shebl, F.M.; Mayne, S.T.; Sinha, R. Coffee drinking and cutaneous melanoma risk in the NIH-AARP diet and health study. J. Natl. Cancer Inst. 2015, 107. [CrossRef] [PubMed]

157. Wang, J.; Li, X.; Zhang, D. Coffee consumption and the risk of cutaneous melanoma: A meta-analysis. Eur. J. Nutr. 2016, 55, 1317-1329. [CrossRef]

158. Liu, J.; Shen, B.; Shi, M.; Cai, J. Higher Caffeinated Coffee Intake Is Associated with Reduced Malignant Melanoma Risk: A Meta-Analysis Study. PLoS ONE 2016, 11, e0147056. [CrossRef] [PubMed]

159. Caini, S.; Masala, G.; Saieva, C.; Kvaskoff, M.; Savoye, I.; Sacerdote, C.; Hemmingsson, O.; Hammer Bech, B.; Overvad, K.; Tjønneland, A.; et al. Coffee, tea and melanoma risk: Findings from the European Prospective Investigation into Cancer and Nutrition. Int. J. Cancer 2017, 140, 2246-2255. [CrossRef]

160. Miura, K.; Hughes, M.C.; Green, A.C.; van der Pols, J.C. Caffeine intake and risk of basal cell and squamous cell carcinomas of the skin in an 11-year prospective study. Eur. J. Nutr. 2014, 53, 511-520. [CrossRef] [PubMed]

161. Song, F.; Qureshi, A.A.; Han, J. Increased caffeine intake is associated with reduced risk of basal cell carcinoma of the skin. Cancer Res. 2012, 72, 3282-3289. [CrossRef] [PubMed]

162. Ferrucci, L.M.; Cartmel, B.; Molinaro, A.M.; Leffell, D.J.; Bale, A.E.; Mayne, S.T. Tea, coffee, and caffeine and early-onset basal cell carcinoma in a case-control study. Eur. J. Cancer Prev. 2014, 23, 296-302. [CrossRef]

163. Caini, S.; Cattaruzza, M.S.; Bendinelli, B.; Tosti, G.; Masala, G.; Gnagnarella, P.; Assedi, M.; Stanganelli, I.; Palli, D.; Gandini, S. Coffee, tea and caffeine intake and the risk of non-melanoma skin cancer: A review of the literature and meta-analysis. Eur. J. Nutr. 2017, 56, 1-12. [CrossRef] [PubMed]

164. Laikova, K.V.; Oberemok, V.V.; Krasnodubets, A.M.; Gal'chinsky, N.V.; Useinov, R.Z.; Novikov, I.A.; Temirova, Z.Z.; Gorlov, M.V.; Shved, N.A.; Kumeiko, V.V.; et al. Advances in the Understanding of Skin Cancer: Ultraviolet Radiation, Mutations, and Antisense Oligonucleotides as Anticancer Drugs. Molecules 2019, 24, 1516. [CrossRef]

165. Arnold, M.; de Vries, E.; Whiteman, D.C.; Jemal, A.; Bray, F.; Parkin, D.M.; Soerjomataram, I. Global burden of cutaneous melanoma attributable to ultraviolet radiation in 2012. Int. J. Cancer 2018, 143, 1305-1314. [CrossRef]

166. Sun, X.; Zhang, N.; Yin, C.; Zhu, B.; Li, X. Ultraviolet Radiation and Melanomagenesis: From Mechanism to Immunotherapy. Front. Oncol. 2020, 10, 951. [CrossRef]

167. Moshinsky, D.J.; Wogan, G.N. UV-induced mutagenesis of human p53 in a vector replicated in Saccharomyces cerevisiae. Proc. Natl. Acad. Sci. USA 1997, 94, 2266-2271. [CrossRef]

168. Viros, A.; Sanchez-Laorden, B.; Pedersen, M.; Furney, S.J.; Rae, J.; Hogan, K.; Ejiama, S.; Girotti, M.R.; Cook, M.; Dhomen, N.; et al. Ultraviolet radiation accelerates BRAF-driven melanomagenesis by targeting TP53. Nature 2014, 511, 478-482. [CrossRef]

169. Menzies, A.M.; Haydu, L.E.; Visintin, L.; Carlino, M.S.; Howle, J.R.; Thompson, J.F.; Kefford, R.F.; Scolyer, R.A.; Long, G.V. Distinguishing clinicopathologic features of patients with V600E and V600K BRAF-mutant metastatic melanoma. Clin. Cancer Res. Off. J. Am. Assoc. Cancer Res. 2012, 18, 3242-3249. [CrossRef] [PubMed]

170. Ratushny, V.; Gober, M.D.; Hick, R.; Ridky, T.W.; Seykora, J.T. From keratinocyte to cancer: The pathogenesis and modeling of cutaneous squamous cell carcinoma. J. Clin. Investig. 2012, 122, 464-472. [CrossRef]

171. Brash, D.E.; Rudolph, J.A.; Simon, J.A.; Lin, A.; McKenna, G.J.; Baden, H.P.; Halperin, A.J.; Pontén, J. A role for sunlight in skin cancer: UV-induced p53 mutations in squamous cell carcinoma. Proc. Natl. Acad. Sci. USA 1991, 88, 10124-10128. [CrossRef] [PubMed]

172. Kim, M.Y.; Park, H.J.; Baek, S.C.; Byun, D.G.; Houh, D. Mutations of the p53 and PTCH gene in basal cell carcinomas: UV mutation signature and strand bias. J. Dermatol. Sci. 2002, 29, 1-9. [CrossRef]

173. Lesiak, A.; Sobolewska-Sztychny, D.; Bednarski, I.A.; Wódz, K.; Sobjanek, M.; Woźniacka, A.; Narbutt, J. Alternative activation of hedgehog pathway induced by ultraviolet B radiation: Preliminary study. Clin. Exp. Dermatol. 2018, 43, 518-524. [CrossRef] [PubMed]

174. Mogha, A.; Fautrel, A.; Mouchet, N.; Guo, N.; Corre, S.; Adamski, H.; Watier, E.; Misery, L.; Galibert, M.D. Merkel cell polyomavirus small T antigen mRNA level is increased following in vivo UV-radiation. PLoS ONE 2010, 5, e11423. [CrossRef] [PubMed]

175. Girschik, J.; Thorn, K.; Beer, T.W.; Heenan, P.J.; Fritschi, L. Merkel cell carcinoma in Western Australia: A population-based study of incidence and survival. Br. J. Dermatol. 2011, 165, 1051-1057. [CrossRef]

176. Wong, S.Q.; Waldeck, K.; Vergara, I.A.; Schröder, J.; Madore, J.; Wilmott, J.S.; Colebatch, A.J.; De Paoli-Iseppi, R.; Li, J.; Lupat, R.; et al. UV-Associated Mutations Underlie the Etiology of MCV-Negative Merkel Cell Carcinomas. Cancer Res. 2015, 75, 5228-5234. [CrossRef] 